\title{
Semiotic Structure of Traditional Japanese Rural Space: Hagikura Village, Suwa Basin
}

\author{
Satoshi Imazato \\ Department of Arts and Sciences \\ Osaka University of Education \\ Kashiwara City, Osaka Prefecture, 582-8582, Japan \\ ima@cc.osaka-kyoiku.ac.jp
}

\begin{abstract}
This paper analyzes the semiotic structure of rural space in a traditional Japanese village, with an economic base of agriculture and forestry, mainly before the end of the country's era of rapid economic growth. This examination defines the interrelationships among the domains of spatial classifications within the village: social space, land-use zones, folk taxonomy, places, village boundaries, symbolic space, and orientation. An abstract system of relationships can be regarded as the spatial deep structure (langue), in contrast to the surface-level structure of rural landscape (parole).
\end{abstract}

Keywords: rural space, folk classification, semiotics of space, landscape as sign, Suwa Basin

\section{Introduction}

A semiotic perspective regards the settlement space of cities and villages as a system of signs composed of landscape and its spatial elements (Brunet 1974:123; Foote 1985:160). Mainly in French, Italian, and English speaking countries, a number of semiotic scholars have discussed such settlement spaces (Foote 1985; Gottdiener and Lagopoulos 1986; Lagopoulos 1994).

A considerable number of studies have also examined the following semiotic elements of landscape and space in African, Asian, and Native American villages: social space (Evans-Pritchard 1969:113-117; Lévi-Strauss 1958:113-180; Tuan 1977:113-116); land folk taxonomy (Conklin 1967; Ohnuki-Tierney 1972:427434); orientation and boundaries (Lagopoulos 1972; Ohnuki-Tierney 1972:439445; Tuan 1974:13-29, 1977:118-135); and symbolic space (Needham 1962; Lagopoulos 1972; Tuan 1974:141-149). These studies mainly clarified the classifications and the cosmology of the villagers' living space.

However, as Yagi (1988a:64-65) pointed out in studies of Japanese village spaces, an important question remains unresolved: although scholars have intensively discussed each domain such as social space, land-use zones, folk taxonomy, places, orientation, village boundaries, and symbolic space, the interrelationships among these domains and their synthesis have not been sufficiently examined.

Traditional Japanese villages can be regarded as native Asian villages. Since the 1950s, the Japanese social sciences have taken up spatial semantic theories of Japanese villages with great controversy in such fields as folklore, cultural anthropology, human geography, history, religious studies, rural sociology, and architecture (Yagi 1998:7-18; Ichikawa 2001:9-41; Suzuki 2004:13-21; Imazato 2006:1544). More recently, in the 1970s and 80s, French semiotics flourished in the humanities and social science departments of Japanese universities. In this context, some geographical studies tried to establish semiotic theories on such settlement spaces as ancient cities and villages (Senda 1980, 1982), historical landscapes (Suizu 1982, 1984), and religious places in villages (Shimazu 1989; Matsuoka 
1992; Ohshiro 1992). However, these spatial semantic studies, as mentioned above, have tended to lack the perspective and logic needed to synthesize the domains of village landscape and space (Yagi 1988a:64-65; Imazato 2006:99).

Keeping such drawbacks in mind, this paper reveals the interrelationships among the spatial domains by introducing a semiotic theory of space, using as a case study the village of Hagikura in central Japan. Various methods and materials were used to pursue this aim: interviews, observations of landscapes and rituals, analysis of cadasters, cadastral maps, and local topographies.

Hagikura, a settlement reclaimed (shinden-syuraku) at the end of the seventeenth century, stands on a river terrace near Lake Suwa in Nagano Prefecture (Figures 1 and 2). It is now a mixed settlement composed of local farmers and newcomers who have arrived from the towns and villages along Lake Suwa since the end of Japan's rapid economic growth. In 1965, the village had only 65 households with a population of 275 ; by 1998 , when the author did his fieldwork, the number of families had increased to 124 with a population of 408 .

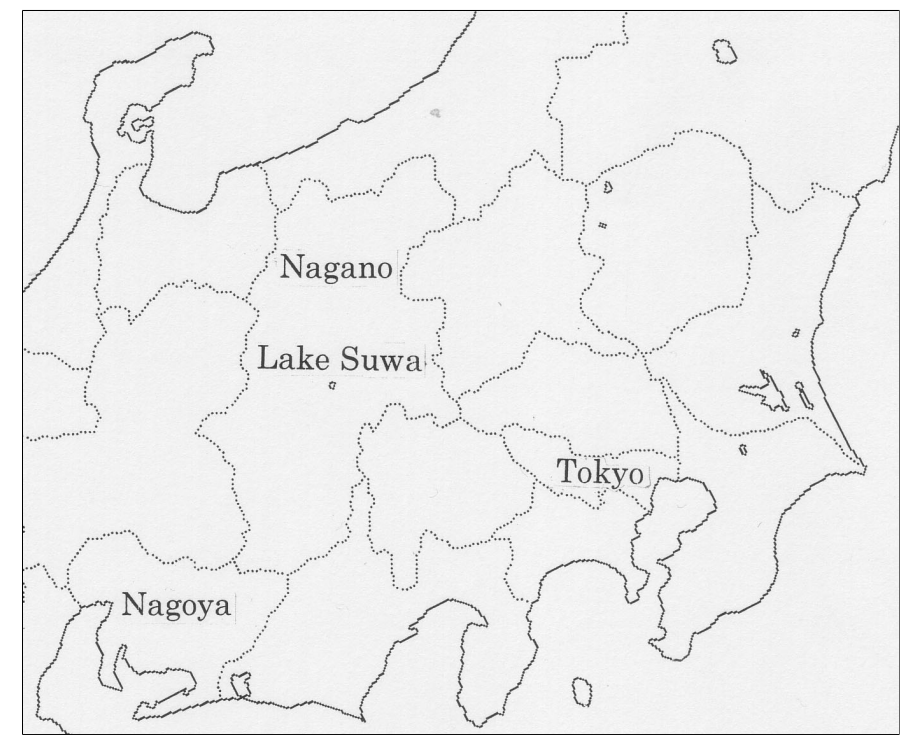

Figure 1. Study area

Hagikura's economy used to be dominated by the farming of rice, wheat, mulberries, potatoes, beans, and other vegetables. Raising silkworms, as well as forestry in the Imperial Forest east of the village, was also important. In recent times, most farmers have also commuted to the bigger towns along Lake Suwa to work in factories or offices.

This paper mainly examines the era before the end of the rapid economic growth in the 1970s, during which most people were engaged in the above agricultural and forestry work. However, most of the spatial classifications examined in this paper remain in use to this day. 


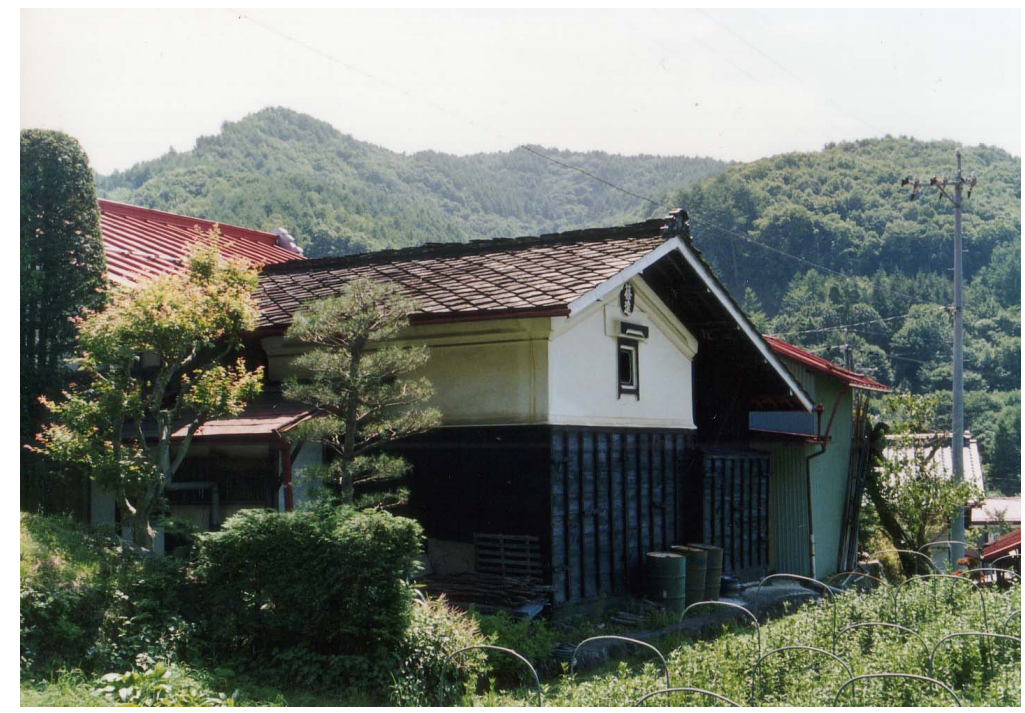

Figure 2. Settlement landscape of Hagikura village Source: Author's photo

\section{Social space, land-use zones, and folk taxonomy}

Generally speaking, in Japanese traditional villages, residents recognized that the entire territory of the village was divided into the following three zones of land use: mura (settlement or residential zone), nora (farmland), and yama (hill) (Fukuta 1980:222). These basic divisions can also be observed in Hagikura (Table 1, Figure $3)$.

Within the settlement zone of a Japanese village, the basic community is typically subdivided into ranks of subgroups (Yamano 1977:415-417). The settlement zone of Hagikura followed such a classification system of social space with the following four ranks: kumi (dual organizations), tou-nakama (mutual-aid groups), han (neighborhood groups), and ie (households). The two dual organizations were called the wade (upstream in the main river of Ohkawa) and shimo (downstream), which were units for fire prevention and fighting, selection of temple parishioner leaders, and so on. These dual organizations were each further classified into two mutual-aid groups, whose main responsibilities included funerals and preparing graves. Each of these groups was subdivided into two neighborhood groups. These eight neighborhood groups within the village were named by number (Group No. 1 , No. 2 ,...No. 8 ).

In the farmland, the folk taxonomy consisted of the following four ranks: subzone, block, minor place, and patch. Each land-use zone was classified into subzones that had specific functions: residential, ritual, and vegetation (Table 1). These sub-zones were composed of blocks labeled with their own names. The names of such blocks (generally called koaza) were also registered in the cadasters of the town government for the collection of taxes. These were subdivided into minor places labeled with names that indicated smaller zones or specific points (Table 2). Such places were further classified into patches or sets of patches with folk names used only within each household. 
Table 1. Upper ranks in folk taxonomy of subsistence space in Hagikura

\begin{tabular}{|c|c|c|c|c|}
\hline & $\begin{array}{c}\text { Rank 1 } \\
\text { Land-use zone }\end{array}$ & $\begin{array}{l}\text { Rank } 2 \\
\text { Sub-zone }\end{array}$ & $\begin{array}{c}\text { Rank } 3 \\
\text { Lower sub-zone }\end{array}$ & $\begin{array}{l}\text { Main land use } \\
\text { or vegetation }\end{array}$ \\
\hline 1 & Mura (Settlement) & - & - & $\begin{array}{l}\text { Houses, vegetables, } \\
\text { ritual }\end{array}$ \\
\hline 2 & Nora (Farmland) & Kage (Behind fields) & - & $\begin{array}{l}\text { Rice, wheat, } \\
\text { mulberries }\end{array}$ \\
\hline 3 & & $\begin{array}{l}\text { Covered category of a } \\
\text { river }\end{array}$ & - & Irrigation \\
\hline 4 & & $\begin{array}{l}\text { Ideira } \\
\text { (Living plateau) }\end{array}$ & - & $\begin{array}{l}\text { Rice, mulberries, } \\
\text { vegetables }\end{array}$ \\
\hline 5 & & Ohkawa (Main river) & - & $\begin{array}{l}\text { Irrigation, washing, } \\
\text { fishing }\end{array}$ \\
\hline 6 & & Mukei (Opposite side) & - & $\begin{array}{l}\text { Mulberries, wheat, } \\
\text { rice, potatoes }\end{array}$ \\
\hline 7 & Yama (Hill) & $\begin{array}{l}\text { Covered category of } \\
\text { hills }\end{array}$ & - & Grass \\
\hline 8 & & $\begin{array}{l}\text { Kageyama } \\
\text { (Back of the hill) }\end{array}$ & - & Grass, firewood \\
\hline 9 & & $\begin{array}{l}\text { O'ne-no-saka } \\
\text { (Ridge's slope) }\end{array}$ & - & Mushrooms \\
\hline 10 & & Urayama (Back hills) & Covered category & $\begin{array}{l}\text { Firewood, lumber, } \\
\text { mulberries }\end{array}$ \\
\hline 11 & & & $\begin{array}{l}\text { Gobayashi } \\
\text { (Common hill) }\end{array}$ & $\begin{array}{l}\text { Ritual, firewood, } \\
\text { mushrooms }\end{array}$ \\
\hline 12 & & & Oyama (Holy hill) & $\begin{array}{l}\text { Ritual, mushrooms, } \\
\text { bamboo }\end{array}$ \\
\hline 13 & & $\begin{array}{l}\text { Haba-no-yama } \\
\text { (Cliffs of a hill) }\end{array}$ & - & $\begin{array}{l}\text { Climate adjustment, } \\
\text { bamboo }\end{array}$ \\
\hline 14 & & $\begin{array}{l}\text { Mukouyama } \\
\text { (Opposite hills) }\end{array}$ & - & $\begin{array}{l}\text { Grass, firewood, wild } \\
\text { plants }\end{array}$ \\
\hline 15 & & $\begin{array}{l}\text { Okuyama } \\
\text { (Mountain depths) }\end{array}$ & $\begin{array}{l}\text { O'heishi } \\
\text { (Imperial Forest) }\end{array}$ & $\begin{array}{l}\text { Firewood, lumber, } \\
\text { wild nuts }\end{array}$ \\
\hline 16 & & & Yashima (Highland) & Grass \\
\hline
\end{tabular}

Note: Each number corresponds to a number in Figure 3. [- ] means that it is not classified.

Source: Author's fieldwork.

In the hill zone, the ranking system was somewhat different from that of the farmland: sub-zone, lower sub-zone, block, and minor place (Tables 1 and 2). This shows that the classification of farmland was more detailed than in the hills. If separated and noncontiguous farmlands existed within the hill zone, their ranking system was the same as that used in the farmland zone.

In short, as subcategories of land-use zones, the social space system classified the settlement landscape into every single house, while the folk taxonomy system classified the landscapes of farmland and hills into minute patches or wider places. These domains of social space, land-use zone, and folk taxonomy of space can be considered to function on the same dimension of spatial classification, although until now they have been regarded as different domains by scholars. They should be regarded as a combined single classification system of 'subsistence space' that consists of six levels from zero to five (Figure 4). 
Table 2. Lower ranks in folk taxonomy of subsistence space: one household

\begin{tabular}{|c|c|c|c|c|}
\hline & $\begin{array}{c}\text { Rank } 2 \\
\text { Sub-zone }\end{array}$ & $\begin{array}{l}\text { Rank } 3 \\
\text { Block }\end{array}$ & $\begin{array}{l}\text { Rank } 4 \\
\text { Minor place }\end{array}$ & $\begin{array}{l}\text { Rank } 5 \\
\text { Patch }\end{array}$ \\
\hline \multirow[t]{2}{*}{2} & Kage (Behind fields) & $\begin{array}{l}\text { Machiyashiki (Plateau } \\
\text { of waiting hut) }\end{array}$ & $\begin{array}{l}\text { Machiyashiki-no-ta } \\
\text { (Machiyashiki } \\
\text { paddies) }\end{array}$ & $\begin{array}{l}\text { Kobbo-ta }(\text { Small } \\
\text { paddy field) } \\
\text { Oh-ta } \\
\text { (Large paddy field) } \\
\text { Maide-sanmai } \\
\text { (Front three patches) }\end{array}$ \\
\hline & & & $\begin{array}{l}\text { Itagasawa } \\
\text { (Paddies along } \\
\text { wooden board brook) }\end{array}$ & - \\
\hline \multirow[t]{4}{*}{4} & $\begin{array}{l}\text { Ideira } \\
\text { (Living plateau) }\end{array}$ & $\begin{array}{l}\text { Hagikura-daira } \\
\text { (Hagikura plateau) }\end{array}$ & - & $\begin{array}{l}\text { Maede } \\
\text { (In front of house) } \\
\text { Uchi-no-shita } \\
\text { (Under house) }\end{array}$ \\
\hline & & $\begin{array}{l}\text { Tokorozawa (Brook } \\
\text { at settlement) }\end{array}$ & $\begin{array}{l}\text { O'haka-no-ta } \\
\text { (Paddies near } \\
\text { graveyard) }\end{array}$ & $\begin{array}{l}\text { Ni-maime (Second } \\
\text { patch from a road) } \\
\text { Nagai-ta } \\
\text { (Long patch) } \\
\text { Nawashiro } \\
\text { (Rice nursery) } \\
\text { Shiro-suna } \\
\text { (White sand ground) } \\
\text { Kurumi-no-ki } \\
\text { (Walnut tree on a } \\
\text { ridge) }\end{array}$ \\
\hline & & & $\begin{array}{l}\text { Tokorozawa-no- } \\
\text { hatake (Tokorozawa } \\
\text { farm) }\end{array}$ & $\begin{array}{l}\text { Dotsubo (Pile of } \\
\text { silkworm dung) } \\
\text { Ume } \\
\text { (Plum tree on a ridge) } \\
\text { Kubo } \\
\text { (Hollow ground) }\end{array}$ \\
\hline & Sub-zone & Lower sub-zone & Block & Minor place \\
\hline 11 & Urayama (Back hills) & $\begin{array}{l}\text { Gobayashi } \\
\text { (Common hill) }\end{array}$ & $\begin{array}{l}\text { Tokorozawa } \\
\text { (Brook at settlement) }\end{array}$ & $\begin{array}{l}\text { Tokorozawa-no-yama } \\
\text { (Hill along } \\
\text { Tokorozawa brook) } \\
\text { Oinarisama-no-yama } \\
\text { (Hill of clan's fox } \\
\text { shrine) }\end{array}$ \\
\hline 14 & $\begin{array}{l}\text { Mukouyama } \\
\text { (Opposite hills) }\end{array}$ & - & $\begin{array}{l}\text { Komokkawa (Hills of } \\
\text { straw mat brook) }\end{array}$ & - \\
\hline
\end{tabular}

Note: This list of patch names includes only some of the sample household. [ - ] means that it is not classified. ( ) indicates English meaning. Each number of sub-zone corresponds to a number in Figure 3.

Source: Author's fieldwork

\section{Place, boundaries, and symbolic space}

In a humanistic geography approach, the word 'place' often indicates points imbued by the local people with symbolic and social meanings (Tuan 1977:85-135). Three major systems of classification exist to define 'place' within the context of a traditional Japanese village. 


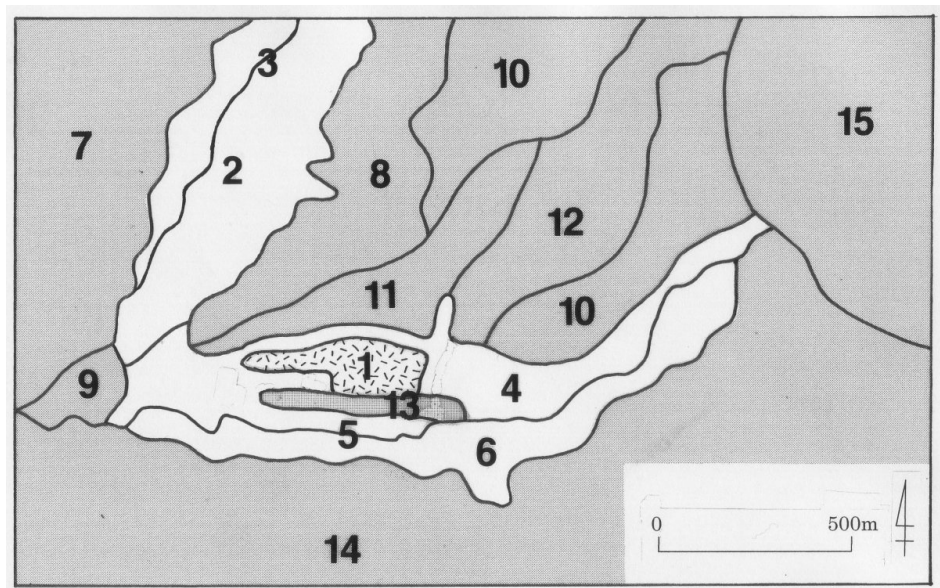

Figure 3. Locations of land-use zones and sub-zones Note: The Yashima zone (No. 16) is east of the O'heishi zone (No. 15). Source: Author's fieldwork, topographical maps, and aerial photographs

First, in Hagikura, Shinto and Buddhist facilities as well as public institutions can be regarded as places (Table 3, Figure 5). In the settlement and hills, a shrine or a series of shrines protect the people working in each land-use zone. Such sacred facilities functioned as the semiotic center of meaning: the main shrine of Yonegami (god of rice) in the settlement zone, the clan's Inari (fox god of agriculture) shrines in the farmland zone (Figure 6), and a mountain deity shrine of Yama-no-kami (forest god) in the hill zone. In the center of the settlement zone, important public facilities were located in an open space, which can be understood as the semantic 'center' of the entire village territory (Figure 5: 1-8).

\begin{tabular}{|c|c|c|c|c|c|}
\hline Rank 0 & Rank 1 & Rank 2 & Rank 3 & Rank 4 & Rank 5 \\
\hline $\begin{array}{l}\text { Village } \\
\text { territory }\end{array}$ & $\begin{array}{l}\begin{array}{l}\text { Settlement } \\
\text { (mura) }\end{array} \\
\text { Farmlands } \\
\text { (nora) }\end{array}$ & $\begin{array}{l}\text { Dual } \\
\text { organizations } \\
(2) \\
\text { Sub-zones } \\
(5) \\
\text { Sub-zones } \\
(7)\end{array}$ & $\begin{array}{l}\text { Mutual aid } \\
\text { groups } \\
(4) \\
\text { Blocks } \\
(10-15) \\
\text { Lower } \\
\text { sub-zones } \\
(10)\end{array}$ & $\begin{array}{l}\text { Neighborhood } \\
\text { groups } \\
(8)\end{array}$ & $\begin{array}{l}\left\{\begin{array}{l}\text { Houscholds } \\
(55-65)\end{array}\right. \\
\left\{\begin{array}{l}\text { Patches } \\
(800-1000)\end{array}\right. \\
\left\{\begin{array}{l}\text { Minor places } \\
(80-100)\end{array}\right.\end{array}$ \\
\hline
\end{tabular}

Figure 4. Folk taxonomy of subsistence space in Hagikura

Note: Parenthesized numbers show the number of categories. For minor places and patches, the numbers are estimated based on samples of one household, village cadasters, and cadastral maps. 
Table 3. Places and their meanings in Hagikura

\begin{tabular}{|c|c|c|c|c|}
\hline & Zone & Place & Main meaning & Onbashira logs \\
\hline 1 & Settlement & $\begin{array}{l}\text { Yonegami main } \\
\text { shrine }\end{array}$ & $\begin{array}{l}\text { God of villge and } \\
\text { center of entire } \\
\text { territory }\end{array}$ & Planted \\
\hline 2 & & Yakushi-dou temple & $\begin{array}{l}\text { Open space and } \\
\text { center of village }\end{array}$ & \\
\hline 3 & & Community center & Ditto & \\
\hline 4 & & Primary school & Ditto & \\
\hline 5 & & Fire-fighting center & Ditto & \\
\hline 6 & & $\begin{array}{l}\text { Agricultural } \\
\text { cooperative }\end{array}$ & Ditto & \\
\hline 7 & & Dousojin stone deity & $\begin{array}{l}\text { God of traffic and } \\
\text { transportation }\end{array}$ & \\
\hline 8 & & God's rice field & $\begin{array}{l}\text { Field attached to the } \\
\text { main shrine }\end{array}$ & \\
\hline 9 & Farmland & Graveyard & $\begin{array}{l}\text { Place of fear near an } \\
\text { inner boundary }\end{array}$ & \\
\hline 10 & Hill & $\begin{array}{l}\text { Fox shrines of the } \\
\text { clans }\end{array}$ & $\begin{array}{l}\text { Gods of clan and their } \\
\text { farmland }\end{array}$ & Planted \\
\hline 11 & & Mountain deity & God of hills & Planted \\
\hline 12 & & $\begin{array}{l}\text { Okuwasama } \\
\text { monument }\end{array}$ & $\begin{array}{l}\text { God of ancestors' } \\
\text { clearing }\end{array}$ & Planted \\
\hline 13 & & Fudou stone saints & $\begin{array}{l}\text { Gods of } \\
\text { mountain-based } \\
\text { asceticism }\end{array}$ & Planted \\
\hline 14 & & Oyama stone saints & Ditto & Planted \\
\hline 15 & & Hachiman shrine & $\begin{array}{l}\text { God of working in } \\
\text { forests }\end{array}$ & \\
\hline 16 & & Kiotoshi shrine & $\begin{array}{l}\text { Guardian of } \\
\text { Onbashira ritual }\end{array}$ & \\
\hline 17 & & Yokitate shrine & Ditto & \\
\hline & Boundary & $\begin{array}{l}\text { Hazure (without a } \\
\text { landmark) }\end{array}$ & $\begin{array}{l}\text { Downstream of inner } \\
\text { boundary point }\end{array}$ & \\
\hline 19 & & $\begin{array}{l}\text { Intersection with a } \\
\text { brook }\end{array}$ & $\begin{array}{l}\text { Upstream of inner } \\
\text { boundary point }\end{array}$ & \\
\hline 20 & & $\begin{array}{l}\text { Pine tree and stone } \\
\text { deities }\end{array}$ & $\begin{array}{l}\text { Downstream of } \\
\text { middle boundary } \\
\text { point }\end{array}$ & \\
\hline 21 & & Pine tree & $\begin{array}{l}\text { Upstream of middle } \\
\text { boundary point }\end{array}$ & \\
\hline 22 & & Stone deities & $\begin{array}{l}\text { Main entrance of } \\
\text { village }\end{array}$ & \\
\hline 23 & & $\begin{array}{l}\text { Fudaba (without a } \\
\text { landmark) }\end{array}$ & $\begin{array}{l}\text { Back entrance of } \\
\text { village }\end{array}$ & \\
\hline
\end{tabular}

Note: Each number corresponds to a number shown in Figure 5.

Source: Author's fieldwork 


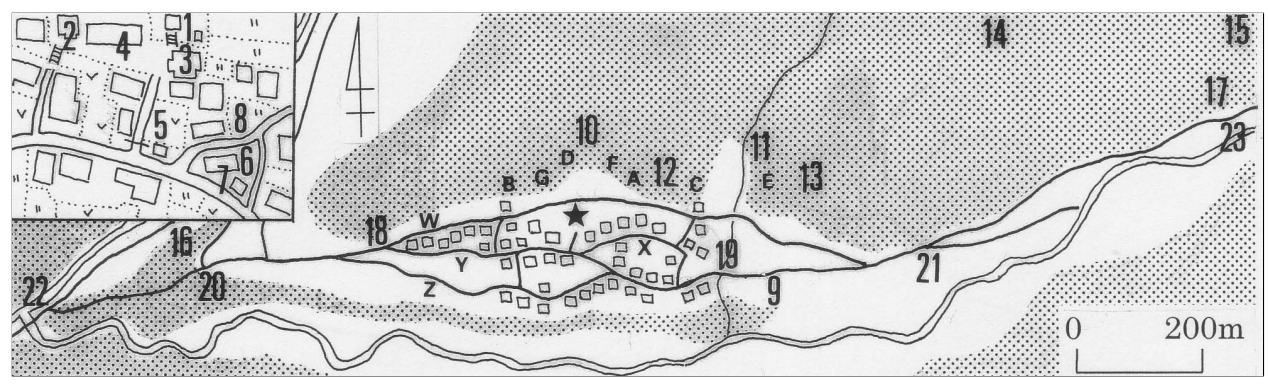

Figure 5. Locations of places and main roads.

Note: Each number corresponds to a number shown in Table 3. Star mark shows the main shrine. Each letter shows a clan's fox shrine (A-G) and one of four main roads (W-Z).

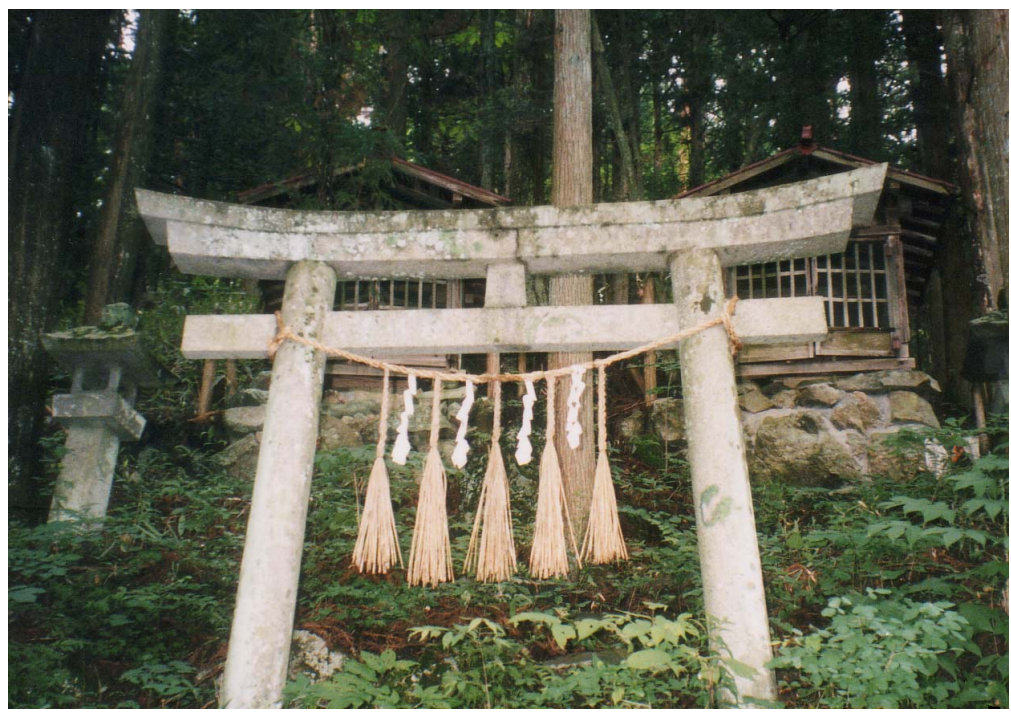

Figure 6. A clan's fox shrine

Source: Author's photo

Second, in contrast to such semiotic 'centers,' the people of Hagikura recognized six boundary points on the periphery of the village territory: inner points between the settlement and the farmland; middle points between the farmland and the hills; and outer points between the hills and the outside world (Table 3, Figure 5: 18-23). These boundary points were marked by such objects as stone statues and isolated pine trees and through varied ritualistic behavior on the main road. In the inner pair, boundaries were formed by a downstream point called Hazure (end of the houses) without any landmark and an upstream point intersecting the Tokorozawa brook near a common graveyard. In the middle pair, the downstream point was marked by a big pine tree, a few stone deities, and a stone monument to a poet; upstream, it was marked by another tall pine tree at a point where paths diverged. The outer pair's boundary points were regarded as the entrances of the village: downstream at an old national highway called the Nakasendo Road, where there were stone deities, a monument to a famous haiku poet (Matsuo Basho), and a tea stall; upstream the boundary point was called Fudaba, the entrance of the Imperial Forest. Some intersections of these six boundary points were also ritual places regarded as sacred places.

Third, these symbolic places and boundaries can also be contrasted between 'sacred places' and 'places of fear' (Shimazu 1989:212-213). In Hagikura, the former places are regarded as the six points of shrines or stone saints in which the people open the Onbashira (literally 'holy log') ritual: the main shrine, a series of the 
clans' fox shrines, the mountain deity, and three areas of stone saints on the common hill of Urayama (Table 3). Onbashira, the most important ritual in the Suwa Basin, is held every six years, when people bring tall logs from the deep mountains of Okuyama and plant them around shrines (Figure 7). Local residents believed that the square zone around a shrine, surrounded by four holy logs, was the source of sacred power.

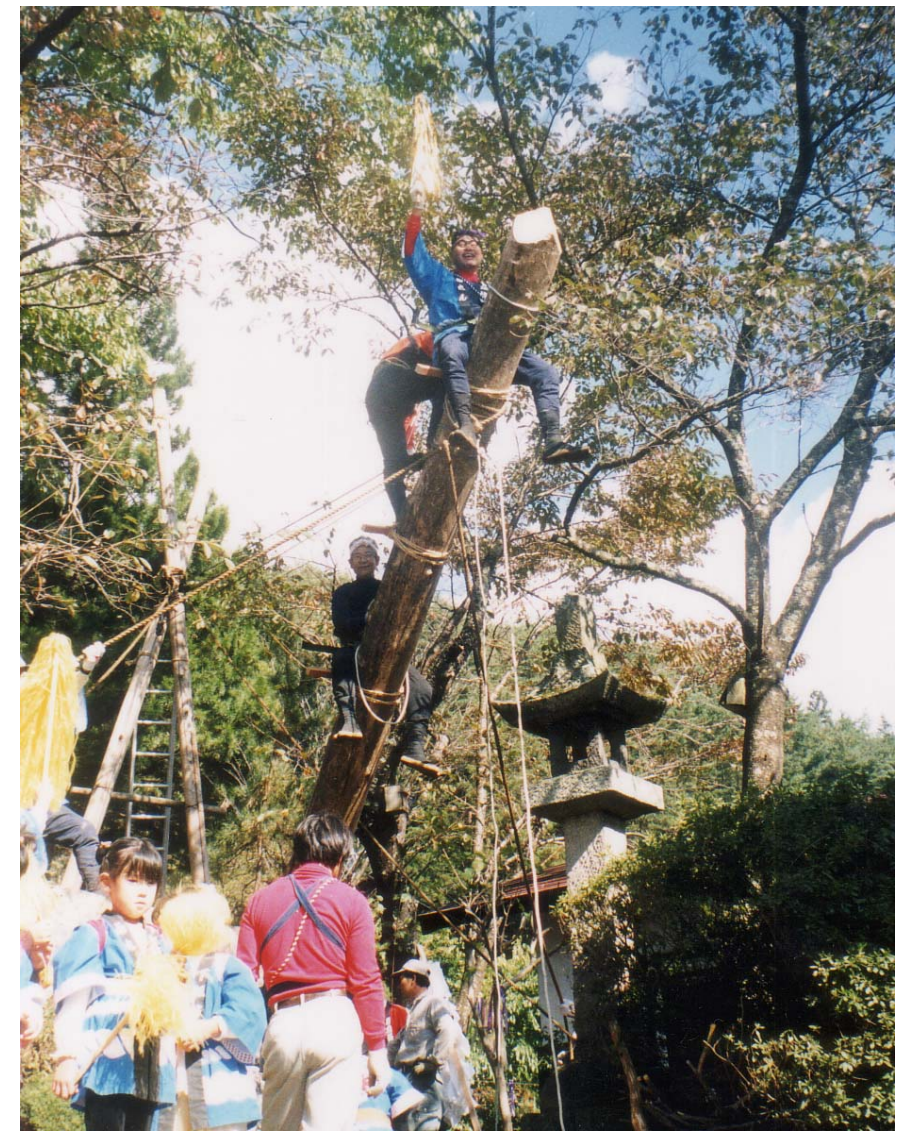

Figure 7. Onbashira planting ritual at the main shrine. Source: Author's photo

By contrast, 'places of fear' were sites where ghosts, devils, and darkness lurked. In the village, such places were predominately concentrated in the boundary points mentioned above and in a periphery 'wilderness' zone of the hills. In Japan, such wilderness hill zones were also cultural spaces of daily subsistence and religion. These boundary points were therefore ambiguous places-both sacred and feared-generally observed in Japanese traditional villages (Yagi 1988b: 144).

Thus, each domain of place, boundary, and symbolic space can be included in a single classification domain of 'place' in the broad sense, although up to now they have been treated as different and separated domains.

\section{Orientation}

The Hagikura people also had their own system of folk orientation. The main shrine of Yonegami was located at the cardinal point of the axes of the north-south and east-west directions: the exact center of the entire territory. Based on the distance from the main shrine, they often used different orientation categories. When referring to locations closer to the settlement zone, they called the south river side omote (front), the north hill side ura (rear), the east upstream wade (upstream), and 
the west downstream shimo (downstream). When referring to locations farther up the hill zone, they called the southward area mukou (opposite), the northward area ue (above), the eastward area higashi (east), and the westward area nishi (west). When indicating intermediate locations within the farmland zone, they used the same categories as in the hill zone, except for the south direction of the lower river terrace, which they called shita (under).

Moreover, the four main roads through the village were referred to by this orientation system: north to south (Figure 5: W-Z), Uwa-michi (upper road); Nakamichi (middle road); Hon-douri (the main road); and Shita-michi (lower road).

In the village, people recognized that to the south they could view the sun in the sky, rice fields, and the opposite hills; in contrast, the north, the rear, was surrounded by woody hills. Almost all shrines also faced south, located on upper or superior sites of the settlement zone. Religious beliefs banned the establishment of shrines facing north. In addition to these sacred buildings, most traditional residential houses also faced south. In 1998, among the 58 traditional houses within the village, $58.6 \%$ faced south, $20.7 \%$ east, $13.8 \%$ west, and only $6.9 \%$ north.

In short, within the village a southerly direction was generally recognized as front and lower, in contrast to the north, which was rear and upper. This orientation principle was prescribed by a typical topography of feng-shui (literally "wind and water') environmental thought developed in ancient China, whose front was a river plateau and whose rear was the surrounding hills (Higuchi 1981:106-131).

\section{Conclusion}

The following general conclusions could be derived from this investigation of Hagikura village. Considering rural space as a system of signs, spatial classification systems (subsistence space, place, and orientation) are abstracted as the logical and deep structure that reflects the tacit understanding of the villagers (Figure 8). This deep structure as langue prescribes the concrete and surface-level structure of landscape as parole: boundary markers (stone deities and pine trees), land-use forms (houses, public institutions, farmland, and woods), and the semiotic centers of land-use zones (shrines).

Previously, Japanese social sciences have considered land-use zones, folk taxonomy, dual organization, and villagers' cosmology, including orientation and boundaries, as different and independent classification domains (Yagi 1988a:6465). However, the author identified the following five interrelationships among these spatial domains. First, land-use zones are the first rank of the landscape folk taxonomy of a village. Second, dual organizations can be considered the second rank of the social space system of a settlement zone. Third, the classification of orientation and boundaries is formed as a grid of coordinate axes and concentric circles, and villagers refer to this grid in their daily activities to orient themselves within the land-use zones. Fourth, the villagers' cosmology is formed by the deep structure or langue that includes all of the spatial systems discussed in this paper. Fifth, even though the abstract deep structure of these classification systems belongs to the syntax of rural space, a symbolic classification system based on the villagers' ideology is on the connotation level of semantics. 


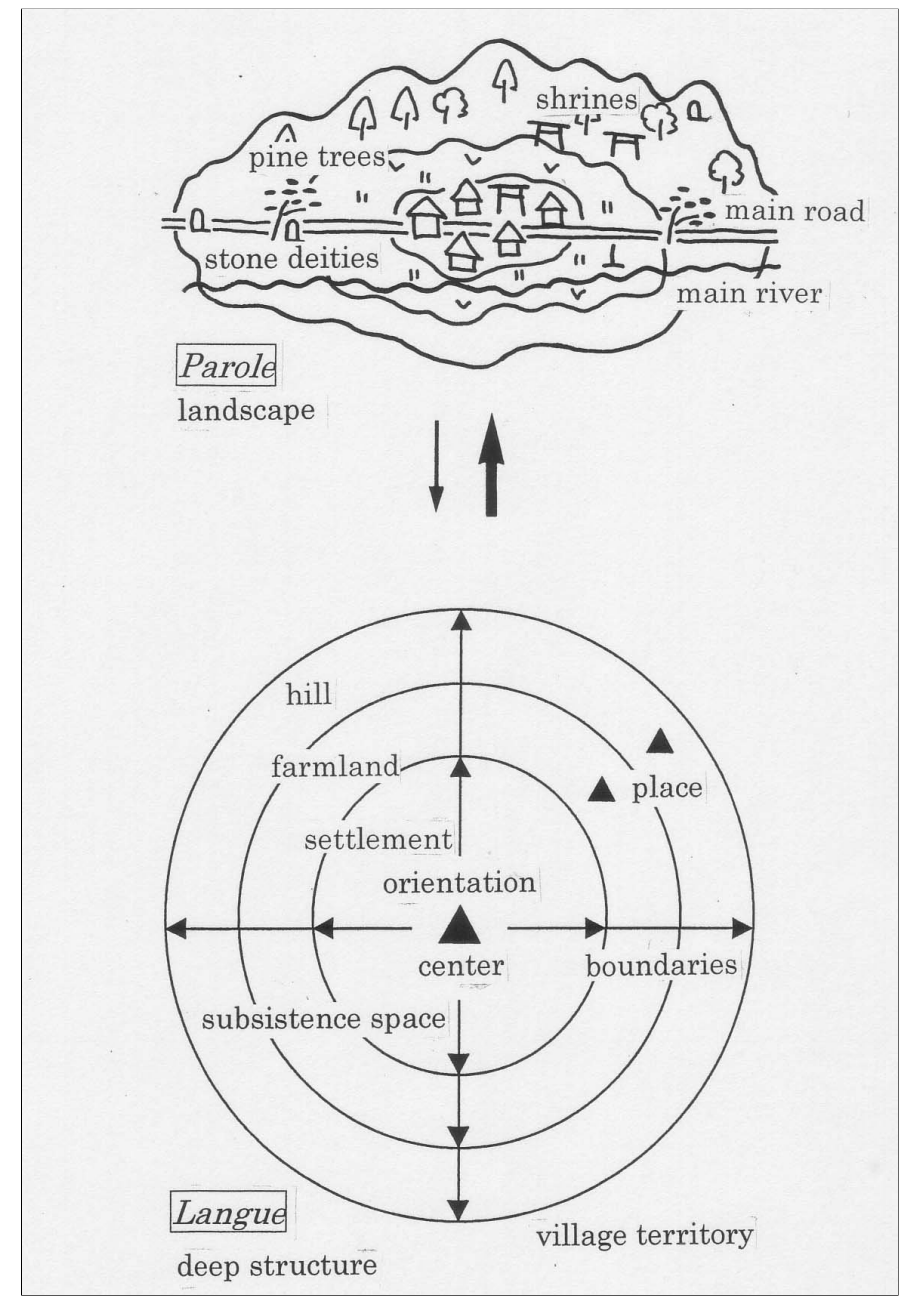

Figure 8. Hagikura's landscape and its deep structure

Beyond the case study reported here, however, some landscape and spatial elements in a village might seem contradictory to and excluded from such a deep structure of langue. In the future, we should examine in detail these folk classification systems of space in other Japanese villages and in other countries' villages to develop the synthetic perspective used in this paper.

\section{Acknowledgements}

This paper is a revised and shortened version of the following article published in Japanese: Imazato, S. 1999 Synthesis of classification categories of rural space: A case study of Hagikura village in central Japan. Japanese Journal of Human Geography 51:433-456. I thank the Human Geographical Society of Japan for permission to publish this English version. I am also grateful to Professors Paul Bouissac, Hiroyuki Matsumoto, and Tetsuya Hisatake as well as anonymous referees for their valuable comments.

\section{References}

[ J ] in Japanese; [ JE ] in Japanese with an English abstract.

Brunet, R. 1974 Analyse des paysages et sémiologie. L'Espace Géographique 3:120-126.

Conklin, H.C. 1967 Some aspects of ethnographic research in Ifugao. Transactions of the New York Academy of Science 30: 99-121. 
Evans-Pritchard, E. E. 1969 The Nuer: A Description of the Modes of Livelihood and Political Institutions of a Nilotic People. Oxford University Press.

Foote, K. E. 1985 Space, territory, and landscape: The borderlands of geography and semiotics. Recherches Semiotiques / Semiotic Inquiry 5:158-175.

Fukuta, A. 1980 Sonraku ryouiki-ron (Territory and community in rural Japan). Musashi Daigaku Jimbun Gakkai Ronsyu (The Journal of Human and Cultural Studies, Musashi University) 12(2):217-247. [ J ]

Gottdiener, M. and Lagopoulos, A. P. ed. 1986 The City and the Sign: An Introduction to Urban Semiotics. Columbia University Press.

Higuchi, T. 1981 Nihon no Keikan: Furusato no Genkei (Japanese Landscapes: Prototypes of Home Villages). Shunjusha. [ J ]

Ichikawa, H. 2001 Hiroba to Sonraku Kuukan no Minzokugaku (A Folklore Study on Rural Open Space). Iwata Shoin. [ J ]

Imazato, S. 2006 The Folk Classification System of Rural Spaces: Reading the Landscape as Text. Kyoto University Press. [ J ]

Lagopoulos, A. P. 1972 Semeiological analysis of the traditional African settlement. Ekistics 195:142-148.

Lagopoulos, A. P. 1994 Settlement space. In Sebeok. T.A. ed. Encyclopedic Dictionary of Semiotics: Volume $2(\mathrm{~N}-\mathrm{Z})$, second edition. Mouton de Gruyter:924936, supplement 10-14.

Lévi-Strauss, C. 1958 Anthropologie Structurale. Librairie Plon.

Matsuoka, T. 1992 A study on the border and spatial structure of the Japanese village: A case study of Kumogahata in Kyoto City. Ritsumeikan Chirigaku (The Journal of Ritsumeikan Geographical Society) 4:77-89. [ J ]

Needham, R.1962 Structure and Sentiment: A Test Case in Social Anthropology. University of Chicago Press.

Ohnuki-Tierney, E. 1972 Spatial concepts of the Ainu of the northwest coast of southern Sakhalin. American Anthropologist 74:426-457.

Ohshiro, N. 1992 Social and historical aspects of landscape: Focused upon ritual facilities in an Okinawan rural settlement. The Historical Geography 159:220. [ JE ]

Senda, M. 1980 A semiotic approach to geographical space. Japanese Journal of Human Geography 32:47-62. [ J ]

Senda, M. 1982 Perceived space in ancient Japan. In Baker, A. R. H. and Billinge, M. ed. Period and Place: Research Methods in Historical Geography. Cambridge University Press:212-219.

Shimazu, T. 1989 Social space and nonprofane places in a Japanese village. Japanese Journal of Human Geography 41:195-215. [ JE ]

Suizu, I. 1982 Chiiki no Kouzou (The Structure of Regions). Taimeido. [ J ]

Suizu, I. 1984 The codes of Japanese landscape: An attempt at topological geography. In Takeuchi, K. ed. Languages, Paradigms, and Schools in Geography: Japanese Contributions to the History of Geographical Thought, Vol. II. Hitotsubashi University.

Suzuki, M. 2004 Cosmology, Ritual, and Space: An Anthropological Study of Tsushima and Okinawa Islands in Japan. Shunjusha. [ JE ]

Tuan,Y-F. 1974 Topophilia: A Study of Environmental Perception, Attitude, and Values. Prentice-Hall.

Tuan,Y-F. 1977 Space and Place: The Perspective of Experience. University of Minnesota Press. 
Yagi, Y. 1988a Some aspects of theories in the spatial classification study of Japanese folk village. Kwansei Gakuin Shigaku (Journal of History, Kwansei Gakuin University) 22:55-67. [ J ]

Yagi, Y. 1988b 'Mura-Zakai': The Japanese village boundary and its symbolic interpretation. Asian Folklore Studies 47:137-151.

Yagi, Y. 1998 Minzoku Sonraku no Kuukan Kouzou (The Spatial Structure of Folk Villages). Iwata Shoin. [ J ]

Yamano, M. 1977 The spatial structure of 'mura' communities in TanbaKibi mountainous district, as viewed from the classification system. Jimbun Kenkyu (Bulletin of the Faculty of Literature, Osaka City University) 29(6):415-437. [ J ] 